\section{s Microscopist Salary Survey:}

In the previous issue of this publicalion, we advised that we were not going to publish the result of our recent microscopist salary survey - due, primarily, to the low number (456) of respondants. However, do to the sizeable number of readers how have requested this information, and with some reluctance, the same is published on the following page.

We wish to state that we offer NO conclusions with this information. However, it may be that some are (and some may not be) interested in the apparent 'trends' in this information.

Many might agree that, with a much wider dala base, the information could be of some real value to the industry. Should you agree, and if you have not previously supplied your data, you are encouraged to do so. With a substantial amount of additional data, we will re-publish the summary at a later date.

- Princeton Gamma-Tech (PGT) has acquired the assets and resources of American Nuclear Systems (ANS) of Oak Ridge, TN. Effective December 1, 1998. The resulting company will operale as Ptinceton Gamma-Tech, Inc. Established in 1965, PGT is recognized as a worldwide leader in $X$-ray microanalysis and nuclear detector technology. William H. Hardy, Ph.D. will serve as Chief Executive Officer of PGT, and Douglas P. Skinner will continue as President of PGT, a position which he has held since March of 1998.

2) Joseph I. Goldstein, Dean of the College of Engineering at the University of Massachusetts, has been named an honorary member of the Microbeam Analysis Society.
Dr. Goldstein is well known in our industry as the "joe" at the Lehigh University series of microscopy courses.

* The 1998 MSA Undergraduate Research Scholarship awards:

1. Jamie Fenimore: The roles of different blood cells in free radical production during encapsulation in Manduca sexta. (Dr. Diana Cox-Foster, Pennsyluania State University)

2. Vincenzo Lordi: Nanomechanics of Carbon Nanotubles (Dr. Nan Yao, Princeton University)

3. Sage Berg-Cross: Defining Tip Characterizations and Edge Detection (Di. Rick Silver, NIST, Gaithersburg, MD).

4. Kelly Davidson: Characterization of mulant sperm cells of the fem Ceratopteris richardii: A correlated light, fuorescence and microsoopy study. (Dr. Karen Renzaglia, Southem Illindis University)

5. Andrew Griffin: ASEM observation of longitudinal axis allignment of silioon carbide whiskers in an orginic matrix. (Dr. Changmo Sung, University of Massachusets - Lowel).

b. Michelle Lail; Glomerulus Development in Organotypic Cultures from Moth Olfactory Labe. (Dr. Leslie Tolbert, University of Arizona)

The 1999 MSA Undergraduate Research Scholarship Progam is currently soliciting applications from students interested in conducting a research project which involves the use of any microscopy technique. Students should be sponsored by a MSA member.

With the application deadline currently at 31 December 1998, interested parties should contact Dr. Ralph Albrecht as soon as possible: (608)2633952, fax. (608)262-7420, eMail: albecht@ahabs.wisc.edu

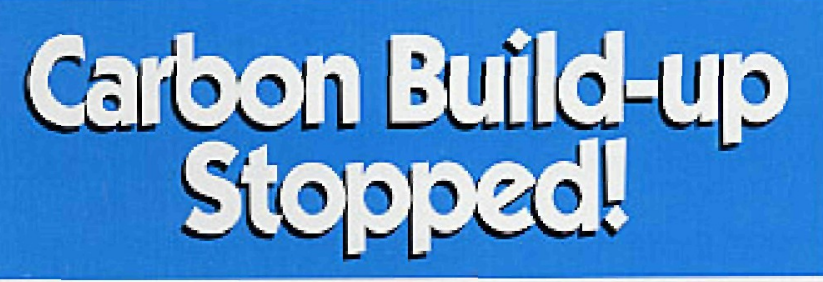

SEM Laboratory Secret Revealed:
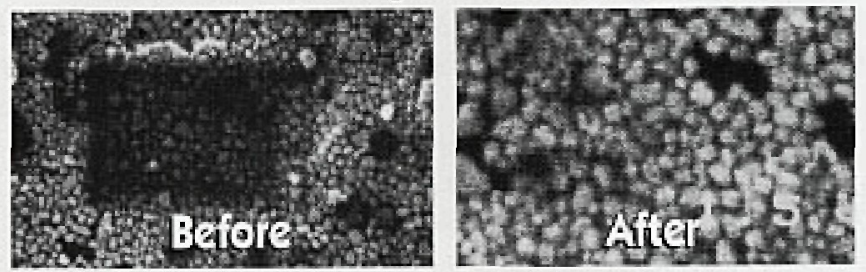

SEM manufacturers won't admit it, but most SEMs are subject to contamination build-up - even dry pumped systems. To stop hydrocarbon condensation, smart SEM users rely on the XEI Scientific SEM-CLEAN ${ }^{\text {n' }}$ system.

Result: Outstanding pictures at low $\mathrm{KV}$ and high resolution and no oil on EDSX-ray detector windows. The Nitrogen purge of the inexpensive SEM-CLEAN system cleans your electron microscope while you're away.

\section{SEM-CLEAN" Stops the Oil}

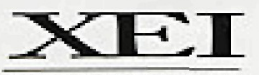

SCIENTIFIC

3124 Wessex Way, Redwood City, CA 94061-1348 $650-369-0133$ - Fax 650-363-1659

http//www.mse.microgcopy.com/SM/XEL/XETHomePage.html

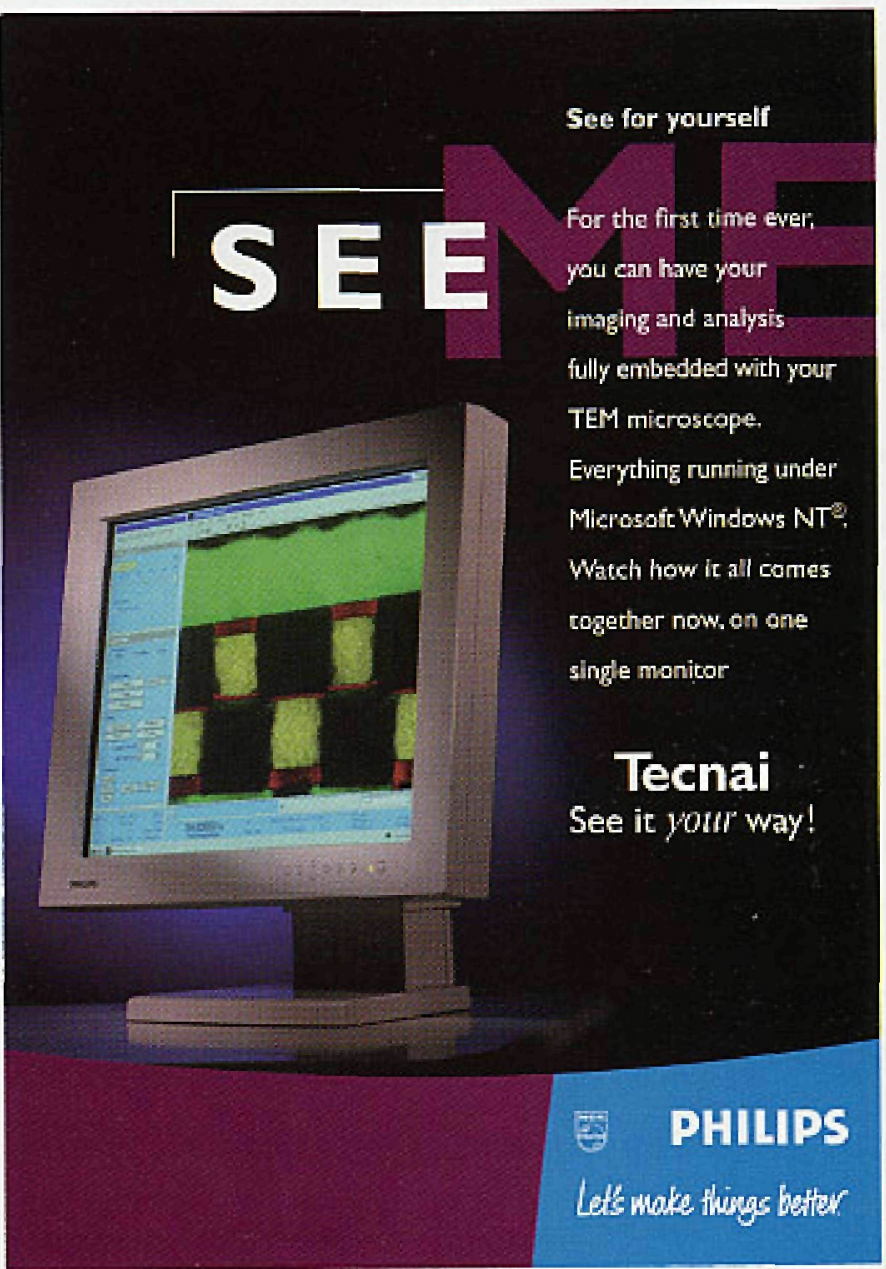




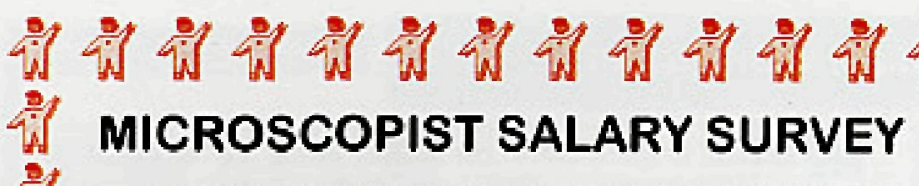
란

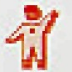

4

:f

4.

4

흔

Nitin

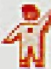

î

*is

i⿱⺈

is

iो

iv

II

if

if

iิ

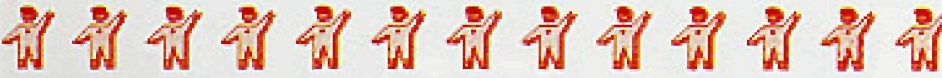

Dus to the relatively small data base, we had decided not to publish the results of the microscoplst salary survey. However, due to the number of individuals that have requested the information, we have changed our mind and offer it as follows.

Should you find the infomation of initial interest, subject to the size of the data base, and have not previously supplied your data, you are encouraged to do so as follows. If we receive sufficient additional data, we will republish the survey at a later date.

In the following table, under degree, the first number (\$) represents average yearly income in thousands of dollars and the second number [I ] indicates the number of entries for that category.

Years

Experience

$1-2.9$

$3-5.9$

$6-8.9$

$9-11.9$

$12-14.9$

$15-17.9$

$18-20.9$

$21=23.9$

$24-26.9$

$27-29.9$

30 PLUS
Education

BS, Etc.

MS, etc.

Ph.D

$\$ 29.6$ (16)

$\$ 31.3(7)$

$\$ 44.1$ (13)

$\$ 36.1$ (10)

$\$ 42.7(11)$

$\$ 54.6$ (20)

$\$ 47.0(15)$

$\$ 56.7$ (12)

559.3 (8)

$\$ 45.7$ (19)

$\$ 50.2(18)$

$\$ 56.2$ (11)

$\$ 48.5(18)$

$\$ 45.9$ (16)

$\$ 57.1(14)$

$\$ 45.0(14)$

$\$ 52.2(16)$

$\$ 67.9(13)$

$\$ 48.7(21)$

$\$ 51.6(21)$

$\$ 71.9(11)$

$\$ 50.4(12)$

$\$ 54.7(6)$

$\$ 62.3(7)$

$\$ 43.4(9)$

$\$ 52.9(8)$

$\$ 75.6(14)$

$\$ 49.8(13)$

$\$ 48.9(3)$

$\$ 71.7(5)$

$\$ 64.6(9)$

$\$ 59.4$ [4]

$\$ 70.9$ (3)
讨

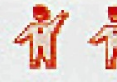

Factors:

We submit that there may be 'factors' which influence salary levels. For example, due to the cost of living might we expect salaries to be higher in California than in, say, Florida.

With this thought in mind, we first computed the average yearly salary for all (457) microscopists - with $\$ 51,676$ as the result. Next, we computed the same for each of the following categories, and compared It to the total average for a percentage deviation.

Gender. Male (268): $\quad+7.7 \%$

Female (189) $-10.9 \%$

Supervisor: Yes (223): $\quad+8.8 \%$

No (233): $\quad-8.4 \%$

Location: $\quad$ Midwest (117): $-3.9 \%$

Northeast (124): $+4.4 \%$

Southeast (70): $-4.9 \%$

South (42): $\quad-16.1 \%$

West- $x \mathrm{CA}$ (45): $-0.1 \%$

Califomia (52): $+20 \%$

Interest

Biological (255):-7.1\%

Physical (182) $+11.6 \%$

Earth (20): $\quad-15.6 \%$

Working In: Industry (171): $+13.4 \%$

Education (160) $-12.7 \%$

Health (B4): $\quad-7.3 \%$

Govt (35): $\quad+8.2 \%$

W/GS scale

Gort $(27): \quad-3.2 \%$

Research Ctr.

Special Note: Due particularly to the size of the data base, we DO NOT suggest any conclusions in the above. The information is supplied only for your posstble interest.

\section{MICROSCOPIST SALARY SURVEY}

If you are interested in expanding our salary survey, and have not previously supplied your data, you are encouraged to do so. With sufficient additional data, we will republish the results. You may do so by Fax, mail or by supplying the information by eNail.

Microscopy Today

PO Box 620122

Middleton. WI 53562

Fax: (608)836-1969

email: microtoday@aol.com

EDUCATION (DEGREE)
None
AA
BS/BAVIC.
MS/etc.
PhD
MDIDVM
EXPERIENCE (YEARS AFTER LAST DEGREE)

GENDER

Male

Female

YEARLY INCOME

$\$$

\begin{tabular}{l} 
CURRENT SUPERVISORMANAGER \\
Yes \\
\hline No
\end{tabular}

LOCATION

If in question, pick the area you feel

closest to your own income location) Midwest

Northeast

Southeast

South

West excluding California Callfornia

PRIMARY INTEREST IN: Biological Science Physical Science Earth Science

WORKING IN Industry

Education Hospital/Medical

Govemment (with GS-Scale) Govemment Sponsored Research Ctrs. 


\section{Gomlng avenTs}

Marine Biological Laboratory Courses, Woods Hole, MA May 6/14 99. Analyical \& Quantitative Light Microscopy May 18/25 '99: Micreinjection Techniques in Cell Bology Oct B/14 Ge: Optical Microscopy \& I maging in the Biomedical Scientes Caral Hamel: (509289-7401, ekail: admissions@mbledu

McCrone Research Institute (Selected) Mlcroscopy Courses, Chicago, IL March 1,599. Conoscopic Methods April 1246 '99: An Introduction to TEM - Techniques and Applicalions April 1246 '99: Advanced FTIR Microscopy June 21/25 \&9 Electronic Image Acquisilion, Procossing \& Analysis Nancy Daer. (312)1842-7100, Fax: (312)1842-107B, ndaerr@meri.org

$\checkmark$ January 68 ' 99 : The 3rd Annual UC Berkeley Microwave Processing Techniques. Workshop (UC Berkeley, Ted Pella, Inc \& Leica). Berkelsy, OA. Kathy Stangenberg: (600)237-352\%, Fax (530)243-3761, ellal tedpelQDaol.com

$\checkmark$ March 7/12 g9: PITTCON '99. Orlando, FL (412)B25-3220, Fax: (412) 825-3224, emal: expopittcon arg

$\checkmark$ March 2225 99: 11th Internatlonal Conferenee on Microscopy of Seniconducting Materials. (RMS \& MRS) University of Oxford. hip/hww, iop.orgiconfs

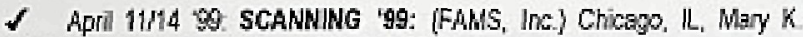
Sullivan: [201818-1010, Fax: (201)818-6086, famsQholonet.net

1 April 11/15 99: FOCUS ON MICROSCOPY 1999 - 12th International Conference on 3D Inage Processing in Mieroscopy \& 11th Internation Conference an Confocal Microscopy (Europeen Molseular Bialogy Laboratory). Heidelberg, Germany hitp:Mwrw,embl-heidelberg delConferencesl FocusOnMicrosoopy

$\checkmark$ LEHIGH MICROSCOPY SCHOOL, Bethlehem, PA

June 1418 Se. SEM and $X$ ray Microanalysis

June 13 'g9: Introduction to SEM and EDS

June 2125 99 . Advanced Scanning Election Microscopy

June 21/25 99: Quantilative X-ray Microanalysis

June 21/24 99: Analylical Electron Mieroscopy

June 2225 '99: Atomic Force Mitroscopy

June 21/24' 99 : Microdiffaction

Info: Ms Sharon Coe: (61077685133, email slo6glehigheds

$\checkmark$ June 1627 99: 3D Microseopy of Llving Cells \& June 20vuly1 99 3D Image Processing Workshop (Uniw of Britsh Columbia) Vancower, BC, Canada. Prof. James Pawly: (608)263-3147, jpawleyglacstaff.wisc odu

$\checkmark$ June 21/25 '99: 15th Annual Short Course on Molecular Microspectroscopy (Miami Universty) $\mathrm{Okford}, \mathrm{OH}$ (513)529-2874, fax [5136297284, enail: hitp/lwww muthio edu-sommeraj

$\checkmark$ June 25JJuly 1 g9: INTER/MICRo '9g (MoCrone Research Institute). Chicago, IL. Nancy Daerr: [312/342-7105

$\checkmark$ July S13 '99: IUMAS 2000: The 2000 Meeting of the Internallonal Union of Microbeam Analysis Societies. Kelua-Kona, Hawaii

$\checkmark$ Aug $1 / 5$ 99. MICROSCOPY \& MICROANALYSIS "g9 (MSA) Porlland, $\mathrm{OR}$

$\$$ Aug 27/29 ge: First Internatlonal Conference On Scanning Probe Microstopy of Polymers, (UCSB \& Digilal Insirumenis). Santa Bartara, CA E.J. Kramer at eckramergmil. vesb ca

\section{$\checkmark$ April 11/3 00: MICRO 2000 (Royal Microscopical Society) London}

$\checkmark$ June 2630 00: 7th Asla-Pacifle Conference on Electron Microscopy Singapore, eMail: micngm|Qnus.edusg or medlab2Qnus,edusg htp:/ww.med.nus.edu.sgimicsoc/apen

$\checkmark$ July $9 / 14$ 00. 12th European Congress on Electron Mleroscopy. Eruno, Czech Republic. hito d/sww eurem2000.isbono.cz'

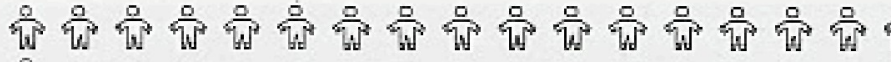
낭

The above is a contribution by Ms. Kimberly Carvalho, a student a the Punahou School in Hawaii. Ms. Carvalho is the daughter of Tina (Weatherby) Carvalho, a frequent contributor to this publication.<smiles>[Li][13CH3]</smiles>

In our continued attempt to make this publication interesting to our readers, we would like to add a bit of humor in each issue. While nice if all related to some aspect of science, we will accept other topios.

To this end, we would greatly appreciate any and all contributions - material, articles, poems, cartoons, whateverHI

\section{Single calls \\ Sung to the tant of Jingle Dells}

Splasing to and tho

Aroutas bife ta play

In a potri dist

Diuiderg one a day

$I$ thought there were tura

Nathing loss at mase

Rut I looked though the mieroseope

And counted up to foust

Ch...

Single colls

Single cells

See how thoy divids

There unas one on ehristmas day

Shut nous maltptied

Single cetls

Single ath

Notfing mesh to do

Dhet owin arawad a petri dish

Druiding into two

Riaddle: If there is ats cell on the first day of Chistmas, fou many amodias will there de on the "turdfth" day of entismat?

Editor
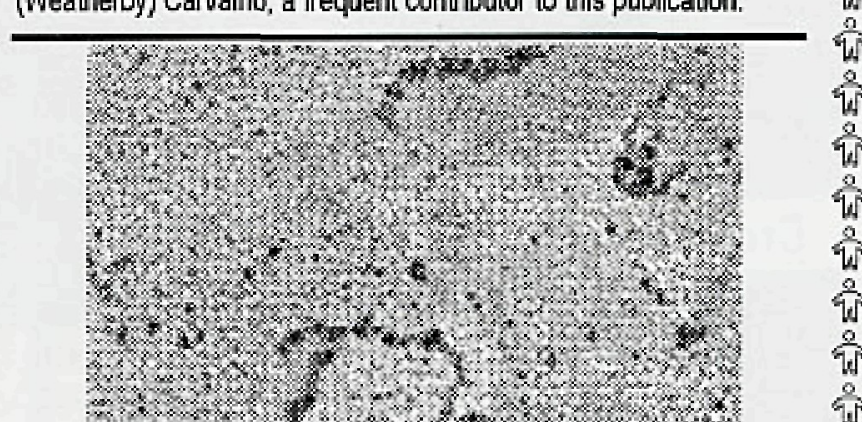

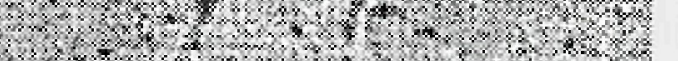
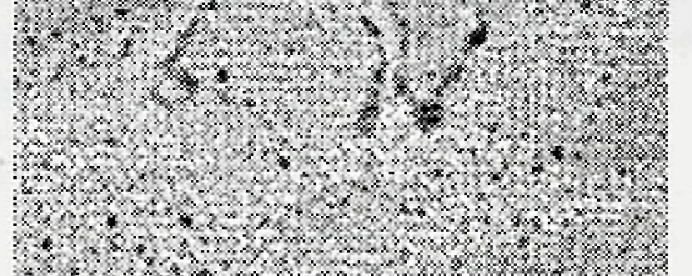

Negative Stain

Contribution from Philip Oshel

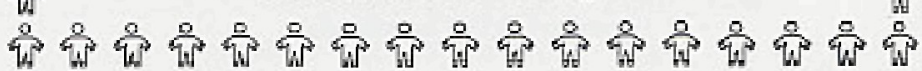




\section{Shortcourses for Microscopists:}

Short courses are opportunities that many practicing microscopists utilize to learn new techniques as well as gain deeper understanding of things they've been doing for years. Several Midwest microscopists have written brief summaries of recent short courses they have attended.

We hope to have this as a periodic forum, so if you've attended a shortourse recently, drop us a line about it.

\section{Lehigh Advanced SEM Course}

by Brad Huggins, Amoco Research Center, Naperville, IL 60563

This past summer I participated in the Advanced Scanning Electron Microscopy with Digital Imaging Short Course at the Lehigh University Microscopy School. This was the third such course that I have attended at Lehigh in the past 10 years, and, as always, this year's course was a very valuable experience. The 4 days were packed with information, learning and opportunity for feedback in the form of classes, lectures and labs. The instructors are world class expertsiteachers in their fields, and the opportunity to interact with them throughout the entire week was unique. Instructors, participants and vendors work and live together on campus for the week.

The course material and agenda were also very good, and appropriate for this advanced section. The week stanted with a review on advanced electron optics, and quickly moved into High Resolution SEM and Digital Image Processing and Analysis. Environmental SEM, Low Voltage SEM, and Stereo Microscopy were also covered in detail. Crystallography in the SEM was a relatively new topic for me, and I am now looking to acquire the instrumentation to apply this technique on our SEMs.

I would rate the overall level of this course as intermediate to advanced, and highly recommend it to experienced microscopists who have a good working knowledge of digital imaging and a strong SEM background. The instructors, staff, and organization of this Short Course are its greatest strengths. The excellent integration of the subject materials covered through the week, combined with the high caliter of instruction and access to a full range of instrumentation'vendors, make this course an opportunity that you'll not likely find elsewhere. If I were to recommend any changes to the course, it would be to make it a full week ( 5 days) which would enable participants to more fully pursue particular areas of interest with the experts who are assembled for the school.

\section{McCrone Research Institute Course Reviews: \\ "Microscopic Identification of Asbestos" "Mineral Grain Identification" \\ "Hotstage Microscopy and Polymorphism" \\ "Advanced Pollen and Spore Identification" by Tony Havics, $\mathrm{pH} 2$ Environmental, Inc.}

The MoCrone Research Institute (MCRl) offers a variely of microscopy courses. I have attended four. They are offered at their South Michigan Ave facility in Chicago with good acosess to both the interstate and airport. The geographic location leaves something to be desired and it results in the Institute bringing in lunch daily (which they pay for, and if they didn't, it's so good that I'd pay for it myself.

The MCRI facility is outfitted with more light microscopes and accessories than could ever be needed - most of an older variety of Nikon. Founded on Walter McCrone's philosophy that the polarized light microscope (PLM) is the best tool for investigatory and R\&D work, few other scopes are notiogable, but they're still present. The asbestos analysis was taught by Peter Cooke, mineral grain identification course instructor was John Delly, hotstage and polymorphism course was hosted by $\mathrm{Dr}$. McCrone hirriself, and $\mathrm{Dr}$. John Shane guided us through the pollen and spore identification course. Each instructor was well

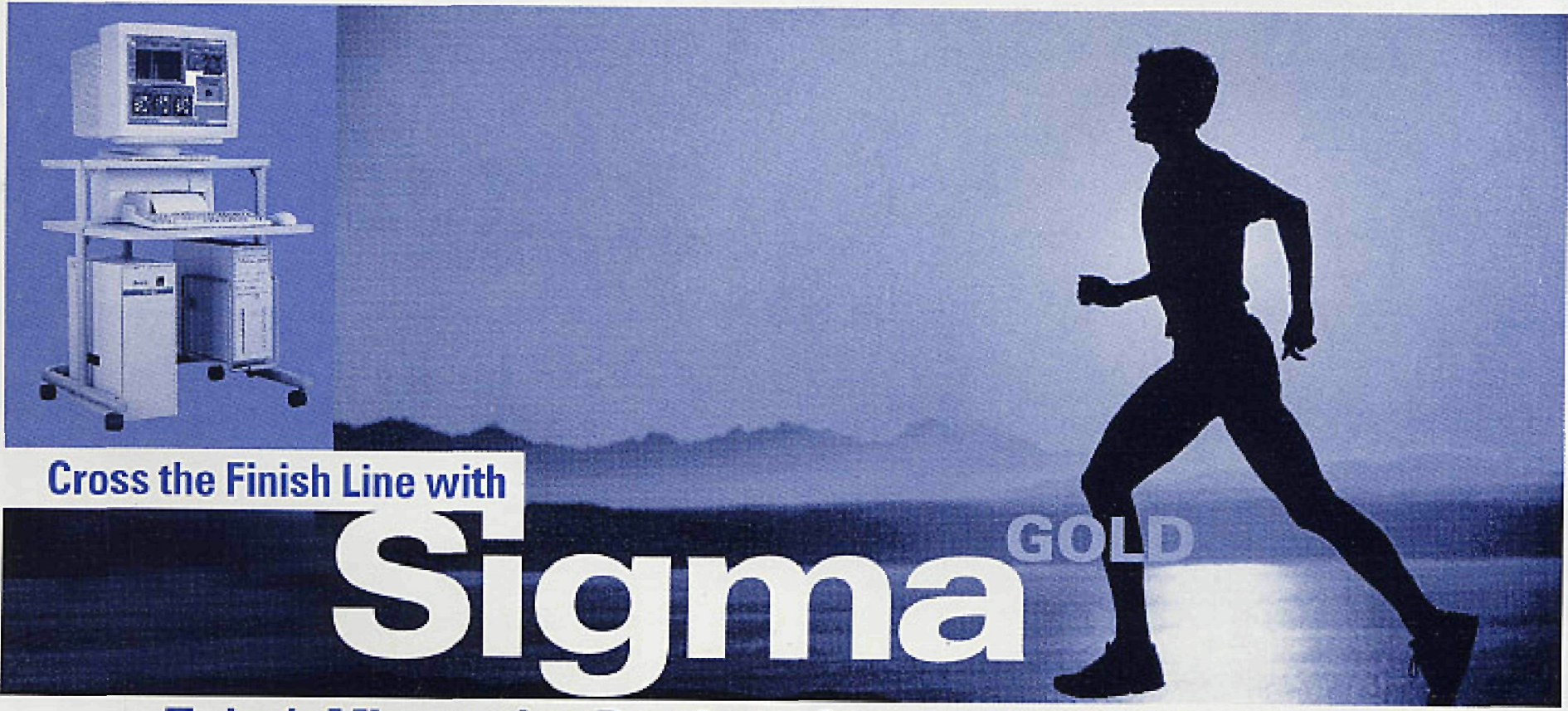

\section{Today's Microanalyst Requires a System with Endurance}

\section{Sigma}

an all-digital microanalyzer

- Now Detector Preamplifier

- Digital Pulse Processor

- Superior light element detector

- 3 types of ATW available

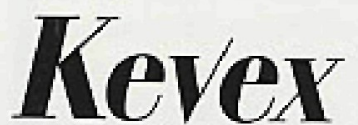

Kowox Instruments 24911 Avenese Stanford, Valencia, CA 91355 Toll-Fiee 800-T0-KEVEX, Phone 805-295-0019, Fax 605-295-8714 Internet htp//wwwkevex.eom, E-miil info@kevex.tom

Kevex-setting the pace for EDS microanalysis 
suited for his respective course considering their backgrounds and teaching styles. The asbestos analysis course using the PLM required a strong foundation in oplics that became tedious at times. The classroom instruction was not as indepth as that of an optical mineralogy course due to the need to practice techriques and onduct real world sample work, but could have been enough to overwhelrn a novice without the proper instructor. This is where Peter Cooke entered. A patient teacher who is fundamentaly sound in his theory, he was capable of seeing the glazing over of a student's eyes . . . and quickly responded with a different perspective to aid in grasping multiple thecries. The course, while not particularly pleasant due to the extended lecturing, was well worth the enhancement of basic optical mineralogy application and fiber identification.

The mineral grain identification course presented less of lecturing style instruction and more of hands-on learning under the scope, looking at morphology and inclusions, performing conoscopic obsenations, learning about source identification by characteristics. When the class seemed to be dragging, John Delly would reveal a novel or interesting apolication of the microsoope - or the specimen for that matter. There seemed to be too litlle time, but the course was enjoyable and I walked away with plenty of new skils and a greater understanding of the subject malter. The hoistage and polymorph course was history incarnate. Little time was spent on the theory of the microscope, but through the week Walter McCrone lead the class through a parsonal tour of the development of holstage (and coldstage) work, from his own work in explosives, circa the 1940 's (which mysteriously became declassified during the course), the liquid crystalline form of Intal, DDT, hydrates and various other fusion preparations. This course was not one for the novice. Given Dr. McCrone's vast experience and a prerequisite course in PLM, it was presumed that the students understood the basics and more (including phase diagrams). No time was wasted on formalities - one immediately dug into provious and current applications as if they were a daily routine. Without my formal education including chemistry, materials science, phase diagrams, and heat transfer, I would have been a litlle frustrated.

The last course I attended was on pollen and spore identification, and like the other courses, the instructor's enthusiasm in this field was only equaled by his skill. The course itself included collecting samples and preparing reierence slides to take back to the office, which look away from the time that might have been better spent on more instruction via slides and the monitor linked to the instructor's scope. Like the rest of the courses, the applications of the field (R\&D, forensics, drug source locating, geologic dating, indoor air quality' were well presented and discussed by the instructor. I acquired a sense of security in my skills, along with an appreciation of my (and any microscopist's) limitations after this course.

As these courses are both for, and attended by, professionals in the workplace, their focus is application. This is not to say that the philosophy and theories are abandoned. The instructors gently probe the students (anywhere from 4 16 in number) the first day and a half to gauge their level of understanding, and from then on quickly fill the woids where necessary. Given that many of the courses were originally 2-weeks each, this is understandable. This is also a disadvantage in that each time I discovered there was far too much material to learn in the allotted time.

An oftentimes overlocked benefit of these courses is the other students. At MCRl l've met and learned from other microscopists: a DNA expert, a Ph.D chemist, military lab scientists, and even a visiting artist. In addition, the instructors welcomed, appreciated, and at times solicited questions and practical advice from the students. Three times I have taken problems to these courses and had them solved. One solution I used in a court case as part of the identification of soil, and a second I used in an air quality investigation at a hospital.

In addition to the camaraderie of the students (and instructors), I was pleased with the reference materials (a thick binder) aoquired from these courses, which I have used many times during my work. The fact that I'm planning to attend two more of McCrone's courses within the next year is the best indicator of my overall satisfaction.

\section{John Mackenzie's Digital Imaging Course at North Carolina State University \\ by John Fournelle, UW-Madison Geology. Eleciron Microprobe Lab}

John Mackenzie runs a 5 day summer school course in Raleigh $\mathrm{NC}_{\text {, offi- }}$ cially listed as BIT697V. I participated in the class this past July. There were 2025 students, mostly graduate students from NCSU, with a few outsiders like myself, It is essentially a practical guide to collection, storage and elementary processing of (microscopic) images. He focuses on the nitty gritty of topics such as resolution of printers (including tricks to yield higher quality cutput on some HP laser printers), scanners, carneras, data storage, image formats.

A significant aspect of the course revolves around usage of Adobe Photoshop, and some essentialisimple (but not widely known) features it has to heip improve the grayscale presentation of images. Mackenzie is great lecturer, is very knowledgeable and has an easygoing manner. He evangelizes his message to "Kick the brightnessicontrast habit" and to utilize the gamma function in Fhotoshop as a better way to bring out the features in ones irrages.

The dass day was divided into 3 hour moming lectures and then 3 hour afternoon omputer labs with Photoshop exercises.

Mackenzie is Coordinator of the Electron Microscopy Center at NCSU. He also runs a highly compressed version of this course at various microscopic meetings, and is scheduled to do so at the upcoming Scanning go meeting in Chicago.

NCSU also hosis a distinct (and highly praised, I am told) Image Processing shortcourse taught by vohn $\mathrm{C}$. Russ, author of the CRC Image Processing Handbook-cost: $\$ 750$ with economical dom acommodations available.

The abowe repinted from the Newsletter and Joumal of the Midwest Microscopy and Microanabsis Society, Volume 26, Number 1, November 1998

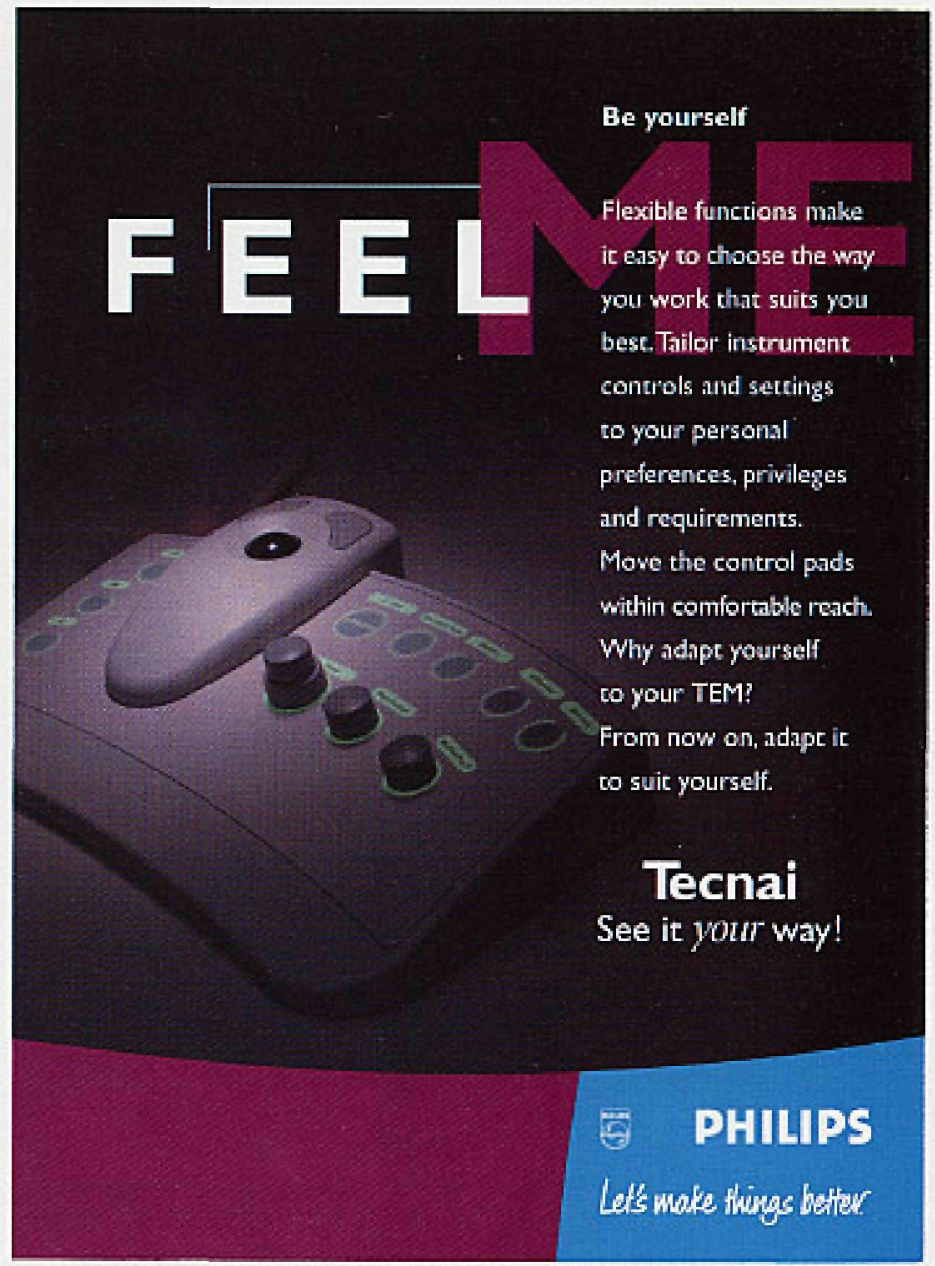

